\title{
Procesy restrukturyzacji w przemyśle okrętowym (na przykładzie Stoczni Szczecińskiej S.A.)
}

Historia budownictwa okrętowego w Szczecinie sięga kilkuset lat, jednak najbardziej dynamiczny okres rozwoju tego sektora przemysłu rozpoczął się od połowy XIX wieku. Najstarszą szczecińską stocznią była stocznia M. Nuscke go jednakże najwaźniejszą rolę odegrała stocznia Vulcan, pierwsza niemiecka stocznia budująca okręty ze stali. Przełomowym był rok 1866, kiedy to przekazano do eksploatacji pierwszy okręt wojenny. Z czasem stocznia Vulcan dostarczała także statki pasażerskie dla armatorów z Hamburga i Bremy oraz statki i okręty dla Rosji, Japonii, Chin i Grecji.

Dobra koniunktura w przemyśle okrętowym Szczecina trwała do końca 1926 roku, kiedy to na skutek kryzysu i konkurencji innych stoczni niemieckich praktycznie zaprzestano produkcji, a stocznia uległa stopniowej likwidacji. Częśsiowo wznowione procesy budowy okrętów podwodnych pod koniec II wojny światowej nie przywróciły stoczni jej pozycji.

Ogromne zniszczenia przemysłu okrętowego w ostatnim okresic wojny przesądziły o tym, że trzeba go było budować w Szczecinie niemal od podstaw. Pierwsze powojenne wodowanie miało miejsce w IV.1948 roku (s/s Oliwa). Było to dokończenie rozpoczętej przez Niemców jednostki. Stępkę pod pierwszą polską jednostkę rudowęglowiec „Czułym"- położono 10.VIII.1951 roku, lecz przekazano go armatorowi dopiero 31.XII.1953 roku. Wszystkie prace prowadzone były na pochylniach ośrodka kadłubowego „Odra” przystosowanego do budowy niedużych jednostek.

W 1957 roku zapadła decyzja o odbudowie zniszczonego ośrodka kadłubowego „Wulkan”( pierwsze wodowanie w 1959 roku). Kolejną zmianą jakościową w działaniu Stoczni Szczecińskiej było dopiero uruchomienie w 1994 roku pochylni „Odra Nowa”.

W ciągu całego swego istnienia Stocznia bardzo elastycznie reagowała na wszelkie zmiany na rynku żeglugowym. Lista rodzajowa zbudowanych jednostek zawiera takie statki jak: rudowęglowce, statki towarowo-pasażerskie, drobnicowce, jednostki hydrograficzne i naukowo-badawcze, kontenerowce, chemikaliowce itp. (tabl. 1). 
Tabl.1. Statki zbudowane w Stoczni Szczecińskiej do końca 1998 roku

\begin{tabular}{|c|c|c|c|c|}
\hline Lp. & $\begin{array}{c}\text { TYP } \\
\text { STATKU }\end{array}$ & $\begin{array}{c}\text { ILOŚ́ } \\
\text { PROJEKTÓW }\end{array}$ & $\begin{array}{l}\text { STATKÓW } \\
\text { ZDANYCH }\end{array}$ & $\begin{array}{c}\text { RAZEM } \\
\text { TYS. DWT }\end{array}$ \\
\hline 1 & Masowiec & 11 & 73 & 2069,90 \\
\hline 2 & Kontenerowiec & 8 & 96 & 1705,40 \\
\hline 3 & Drobnicowiec & 17 & 154 & 1313,50 \\
\hline 4 & Produktowiec & 5 & 11 & 393,00 \\
\hline 5 & Semikontenerowiec & 4 & 25 & 382,30 \\
\hline 6 & Chemikaliowiec & 2 & 13 & 342,40 \\
\hline 7 & Okręt warsztatowy & 4 & 39 & 182,00 \\
\hline 8 & Rudowęglowiec & 1 & 41 & 130,10 \\
\hline 9 & Towarowo - pasażerski & 4 & 13 & 42.00 \\
\hline 10 & Oceanograficzny & 2 & 17 & 93,50 \\
\hline 11 & Szkolno - towarowy & 1 & 13 & 71,60 \\
\hline 12 & Holownik zaopatrzeniowy & 2 & 48 & 66,30 \\
\hline 13 & Statek elektrownia & 1 & 4 & 21,60 \\
\hline 14 & Szkolny okręt rakietowo - artyleryjski & 1 & 3 & 21,80 \\
\hline 15 & Prom pasażersko - samochodowy & 3 & 12 & 22,90 \\
\hline 16 & Naukowo - badawczy & 2 & 13 & 18,40 \\
\hline 17 & Szpital & 1 & 4 & 13,60 \\
\hline 18 & Geofizyczny & 1 & 9 & 11,80 \\
\hline 19 & Okręt desantowy & 1 & 1 & 3,90 \\
\hline 20 & Prom drogowy & 1 & 4 & 3,20 \\
\hline 21 & Statek dźwigowy & 1 & 4 & 1,50 \\
\hline 22 & Inne typy & 2 & 2 & 3,80 \\
\hline \multicolumn{2}{|r|}{ Razem } & 75 & 599 & 6914,50 \\
\hline
\end{tabular}

Źródło: Stocznia Szczecińska S.A. Raport Roczny 1998.

Ogromnym osiągnięciem była seria 12 chemikaliowców ( 28 tys.DWT nośności) zbudowanych $w$ latach 70-tych dla Norwegii. Byl to największy na świecie kontrakt w zakresie budowy tego typu statków.

Wielką rangę uzyskały projektowane i budowane w Szczecinie jednostki unikatowe takie jak statek-szpital (przystosowany do wykonywania nawet najhardziej skomplikowanych operacji w trudnych warunkach morskich) oraz kompleksy hiperbaryczne, umożliwiające nurkom w miękkich skafandrach pracę przy obsłudze konstrukcji morskich na głębokościach do $250 \mathrm{~m}$. Montowane były na statkach badawczych i platformach wiertniczych. Inne ich wersje znalazły zastosowanie na lądzie w szpitalach zajmujących się problemami hiperbarii i tlenoterapii. 
Następstwa kryzysu gospodarczego w Polsce dotknęły cały przemysł okrętowy. Z dostępnych w szeregu publikacjach danych wynika, że zadłużenie tej gałęzi przemysłu w Polsce osiągnęło poziom około 6 bln zł ( Piotrowski K.,1994). Ministerstwo Przemysłu i Handlu szacowało, że rekonstrukcja tego przemysłu pochłonęłaby co najmniej 16 bln zł. Nasuwały się więc pytania: czy polską gospodarkę stać na taką inwestycję czy raczej zlikwidować tę dziedzinę gospodarki? W sytuacji gdy zapadnie decyzja o ratowaniu przemysłu stoczniowego nasuwają się dalsze pytania: jak przeprowadzić operację oddłużenia i restrukturyzację w warunkach funkcjonującego przedsiębiorstwa?, w jaki sposób zabezpieczyć co najmniej 500 mln USD w formie gwarancji i kredytów na realizację kontraktów i jak sprostać coraz silniejszej konkurencji europejskich i azjatyckich potentatów stoczniowych? Na te i szereg innych pytań należało znaleźć odpowiedź moźliwie najszybciej nie tylko na szczeblu rządowym, ale przede wszystkim w samych stoczniach . Stocznia Szczecińska rozpoczęła przygotowania programu naprawczego oraz jego wdrażanie $\mathbf{w}$ warunkach pogłębiającego się kryzysu gospodarczego.

Od połowy 1989 roku sytuacja finansowo-produkcyjna Stoczni stopniowo pogarszała się. Ponadto, w 1991 roku nastąpiło załamanie się wymiany handlowej z rozpadającym się Związkiem Radzieckim. Oznaczało to rezygnację z budowy 9 zamówionych statków oraz nie odebranie 3 jednostek już gotowych. W tym samym roku zlikwidowane zostały gwarantowane przez rząd dopłaty wyrównawcze do eksportu statków dla armatorów angielskich i hinduskich. Drastycznie wzrosło oprocentowanie kredytów bankowych. Tym samym Stocznia utraciła zdolność kredytową, wystąpiły także ogromne trudności z płynnością finansową firmy.

Rysujące się już od 1989 roku problemy wskazywały na potrzebę bardzo szybkich i bardzo radykalnych zmian, które mogłyby zahamować proces upadku zakładu.

Już w IV.1991 roku zarządzanie Stocznią powierzono nowej dyrekcji, która zapoczątkowuje proces prywatyzacji firmy przekształcając ją w jednoosobową spółkę skarbu państwa ( od 28.VIII.1991r nosi nazwę Stocznia Szczecińska S.A.). Program ratowania i sanacji firmy obejmował następujące podstawowe zadania:

- poprawę produktywności poprzez zmianę systemów płac, organizacji procesów wytwarzania, wdrożenie nowych technologii o niższej pracochłonności i krótszych cyklach produkcyjnych, głębokie zmiany struktury zatrudnienia;

- restrukturyzację finansową przez przeprowadzenie postępowania układowego, odzyskanie zdolności kredytowej i uzyskanie gwarancji banków zachodnich na przedpłaty armatorów;

- reorientację kierunku eksportu na rynki zachodnie;

- etapową prywatyzację firmy i dążenie do utworzenie grupy przemysłowofinansowej, z wiodącą rolą Stoczni.

Przestawiony program różnił się w poważnym stopniu od programów innych stoczni. Rok 1991 zakończył się dla firmy wynikiem negatywnym, przekazano armatorom tylko 5 jednostek ponosząc na ich sprzedaży ogromne straty.

Rozpoczęto 1992 rok ze stratą bilansową 99,5 mln PLN, która nadal zwiększała się z tytułu naliczania odsetek od nie spłacanych długów. Powołując się na fakt, że straty nie powstały z winy Stoczni, wniesiono do Sądu Rejonowego w Szczecinie wniosek o otwarcie postępowania układowego $\mathrm{z}$ wierzycielami. 
W okresie przygotowywania wniosku nastapiło szczególne wydarzenie. Bank Gdański finansujący Stocznię skierował w III.1992 roku do premiera J.Olszewskiego wniosek o ogłoszenie upadłości Stoczni. Dzięki wielu staraniom zarządu wniosek został oddalony. Jednak gdyby stało się inaczej, proces restrukturyzacji byłby zatrzymany a skutki trudne do przewidzenia.

Zawarty z wierzycielami układ uprawomocnił się 18.XI.1992 roku. Całkowite zadłużenie Stoczni Szczecińskiej wynosiło ok.2,6 bln zł, z czego procesem układowym objęto 1,8 bln zł. Zgodnie z nim, wierzytelności Stoczni uległy $33 \%$ redukcji (głównie odsetki) a spłata długów została odroczona i rozłożona na 20 rat, płatnych od grudnia 1993 roku. Pozwoliło to na odzyskanie płynności finansowej i regulowanie zobowiązań na bieżąco.

Podjęte zdecydowane działania w zakresie reorganizacji systemów zarządzania pozwoliły na znaczne skrócenie cyklu budowy statków już w 1992 roku oraz trzykrotne zwiększenie sprzedaży (13 jednostek za 184 mln USD). Już w 1993 roku Stocznia została sklasyfikowana na 3 pozycji wśród polskich eksporterów (w 1994 r -miejsce 4).

W tym okresie Stocznia Szczecińska S.A stawiana jest za przykład prawidłowo prowadzonej restrukturyzacji i wymieniana jako jedna z dwóch stoczni mogących skutecznie tworzyć grupe przemysłowo-kapitałową. W 1996 roku, po raz pierwszy w 48-letniej historii, roczny obrót Stoczni przekroczyl $500 \mathrm{mln}$ USD. Wyniki produkcyjne i wielkość portfela zamówień pozwoliły na sklasyfikowanie SSSA w pierwszej dziesiątce największych stoczni świata (rys.1).

Na dobre wyniki Stoczni i jej pozycję wpływały nie tylko podjęte przez zarząd działania. Sprzyjała im także ogólnie dobra koniunktura w światowym przemyśle okrętowym.

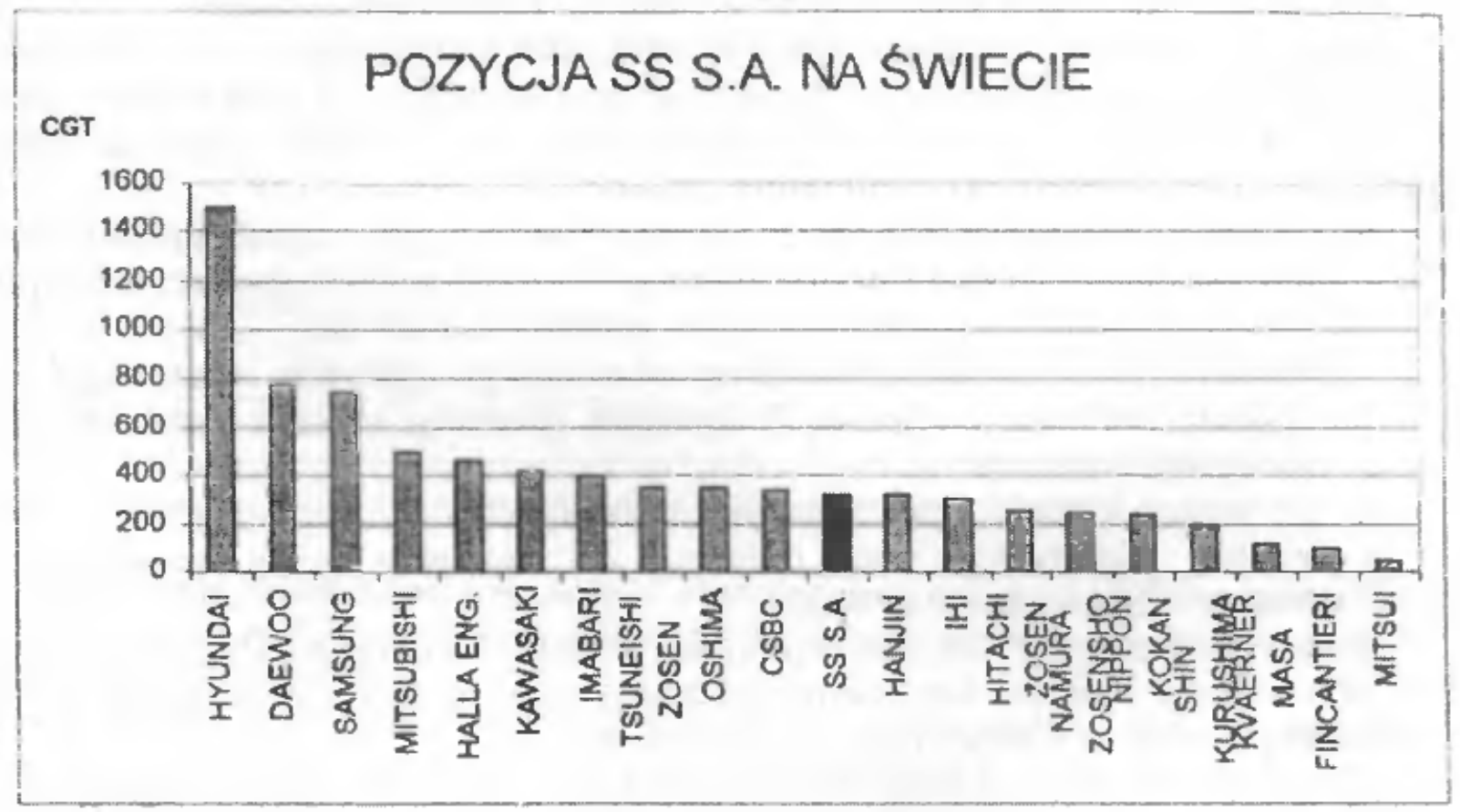




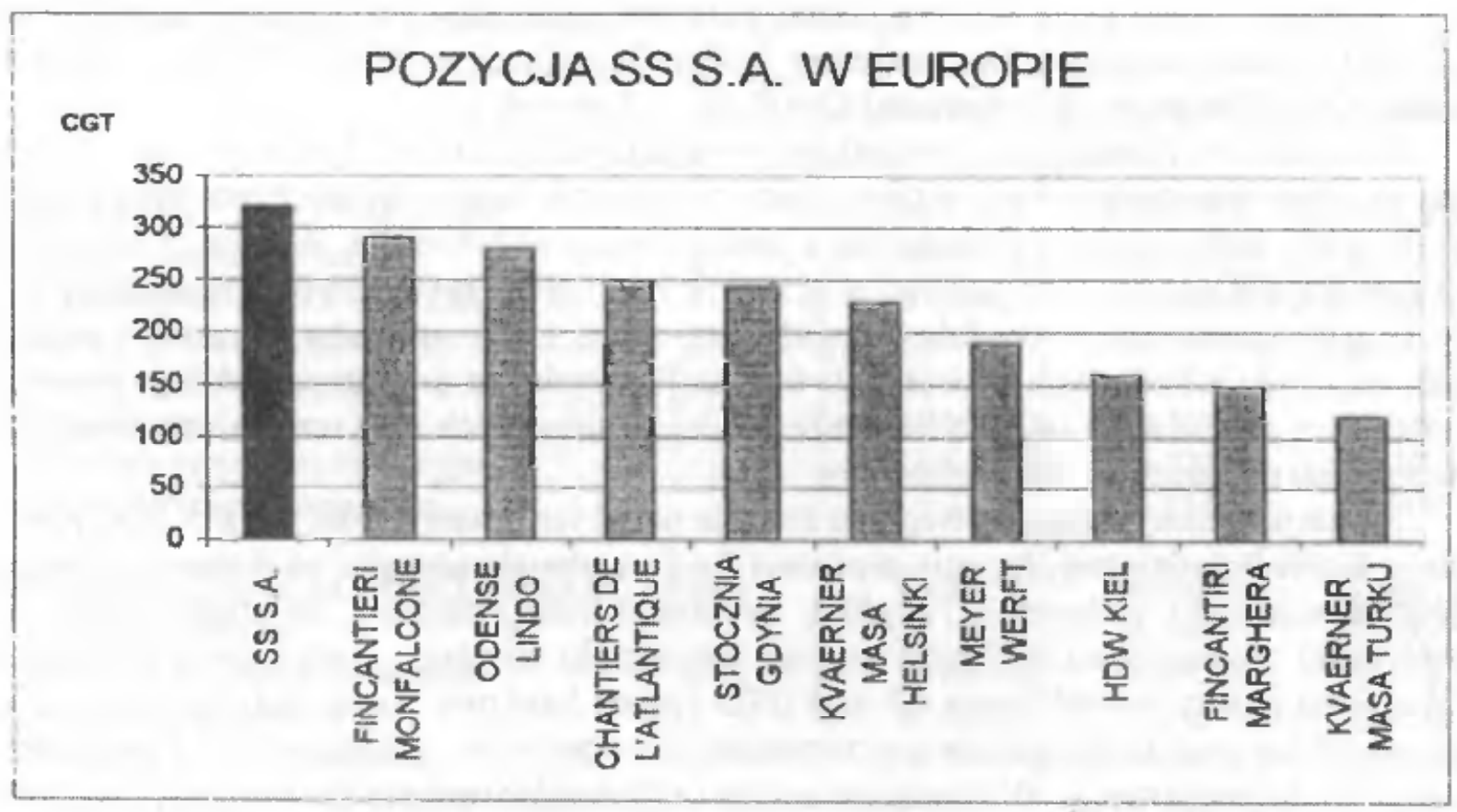

Zródlo:SS S A

Rys. 1. Miejsce Stoczni Szczecińskiej S.A w 1998r. W Europie i na świecie

Pierwsze oznaki pogorszenia się sytuacji pojawiły się w 1996 roku. W wyniku rozbudowy stoczni dalekowschodnich i trwałej tendencji do zwiększania produktywności stoczni na świecie, ceny na typowe statki towarowe spadły o 20-30\% w stosunku do poziomu z początku lat 90-tych. Wystąpiły także inne uwarunkowania rynku światowego, które ograniczyły konkurencyjność polskich stoczni. Były to m.in.:

- nasycenie rynku kontenerowcami średniej wielkości ( jedna ze specjalności Stoczni);

- zmiany prawa podatkowego w Niemczech ograniczające atrakcyjność prywatnych inwestycji żeglugowych;

- aprecjacja dolara USA i japońskiego jena w stosunku do waluty koreańskiej, co radykalnie zwiększyło konkurencyjność tamtych stoczni (znaczny wzrost zamówień dla stoczni Dalekiego Wschodu);

- nie ratyfikowanie przez USA w 1996r Porozumienia OECD o eliminacji subsydiów stoczniowych. Oddaliło to perspektywę zwiększenia konkurencyjności wobec innych stoczni europejskich.

Prowadzona polityka inwestycyjna w latach 1994-96 pochłonęła $211 \mathrm{mln}$ PLN, z czego najważniejsze były: budowa ośrodka Odra Nowa, system CAD/CAM, zmiana technologii spawania, oddanie do eksploatacji urządzenia do cięcia plazmowego stali.

Prestiżowym osiagnięciem było zakupienie przez kanadyjską stocznię St. John licencji na budowę kontenerowca z serii B 186 oraz sprzedaż dwóch statków prototypowych - produktowca (B578) o nośności 40 tys. DWT dla Shell Australia oraz masowca (B577) o nośności 45 tys. DWT dla armatora z Chile.

W obliczu spadku zainteresowania kontenerowcami średniej wielkości Stocznia zmienia strukturę swojej oferty. W podpisanych kontraktach większość zamówień przypada na otwarte masowce i zbiornikowce do transportu chemikalii (dla Norwegii, Singapuru i Grecji). 
Wyroby Stoczni mają wysoką jakość potwierdzoną kolejnym 3-letnim certyfikatem ISO 9001, nadanym przez Germanischer Lloyd Certiffication $\mathrm{GmbH}$, Polskie Centrum Badań i Certyfikacji oraz International Certification Network .

Rok 1998 był jubileuszowym rokiem w działalności Stoczni Szczecińskiej (50 lat) oraz waźnym dla stoczni i jej akcjonariuszy. Najistotniejszym wydarzeniem było zakończenie spłaty zobowiązań wynikających z postępowania układowego. W ciągu 6 lat zwrócono wierzycielom $156147484,70 \mathrm{zł} \mathrm{tj.} \mathrm{ok.} 78 \mathrm{~min}$ USD. Był to również rekordowy rok pod względem rozmiarów produkcji pojedynczej stoczni. Do sukcesów roku 1998 należy także zaliczyć: zakończenie procesu prywatyzacji, uzyskanie poprawy struktury finansowania przez zwiększenie udziału kredytów średnioterminowych oraz umocnienie wysokiej pozycji jako producenta chemikaliowców.

Sytuacja przemysłu okrętowego na świecie nadal jest niezbyt korzystna. Kłopoty walutowe Korei Południowej, Japonii, a później Rosji, wpłynęły ujemnie na dynamikę handlu międzynarodowego $\mathrm{w}$ basenie Pacyfiku. W konsekwencji zmalało zapotrzebowanie na nowe statki. Sytuację europejskich stoczni pogorszyło działanie Światowego Funduszu Walutowego, który wsparł kwotą 57 mld USD system bankowy Korei Płd. Znaczna część tych pieniędzy została niezgodnie z przeznaczeniem ponownie „wtłoczona" do koreańskiego przemysłu okrętowego. W rezultacie zaczął on kontraktować statki stosując ceny dumpingowe o ok. $25 \%$ niższe niż dotychczas stosowane.

Nowa sytuacja na rynku okrętowym stała się kolejnym wyzwaniem dla Stoczni. Chodziło o opracowanie takiej strategii, która pozwoliłaby sprostać konkurencji i znaleźć taką „niszę” produktów, w których Stocznia Szczecińska będzie trudnym konkurentem dla innych stoczni.

W podsumowaniu 1998 roku naleźy stwierdzić, że nie tylko zakończył się on pozytywnym wynikiem finansowym (tabl.2). W portfelu zamówień znalazły się m.in. chemikaliowce i statki typu ro-ro. Trwają także bardzo intensywne prace nad tworzeniem holdingu przemysłowego.

Przełomowym w historii Stoczni stał się rok 1999. Tworzona ciągle struktura holdingowa ma być bardziej odporna na dekoniunkturę gospodarczą i ułatwić dalsze procesy restrukturyzacyjne. Zadania na najbliższą przyszłość $(2000-2001)$ to: obniżenie kosztów własnych Stoczni, zagospodarowanie majątku nie fabrycznego, poprawa efektywności tzw. firm „córek” i ulokowanie niektórych z nich na WGPW.

Jest to również kolejny trudny rok na rynkach światowych, co w sposób istotny rzutuje na sytuację polskiego przemysłu okrętowego. Notuje się spadek zapotrzebowania na przewozy morskie, co wpływa na zmniejszenie się stawek frachtowych i w dalszej konsekwencji - na zmniejszenie się zamówień na nowe statki. 
Tab.2. Rachunek zysków i strat za lata 1996 - 1998.

\begin{tabular}{|c|c|c|c|}
\hline & $\begin{array}{l}\text { 31.12.1996 } \\
\text { ( tys. zl) }\end{array}$ & $\begin{array}{l}\text { 31.12.1997 } \\
\text { ( tys. zl) }\end{array}$ & $\begin{array}{l}31.12 .1998 \\
\text { ( tys. zl) }\end{array}$ \\
\hline \begin{tabular}{|l|} 
PRZYCHODY ZE SPRZEDAŻY \\
Koszt własny sprzedaży \\
\end{tabular} & $\begin{array}{l}1378148,3 \\
1184760,3\end{array}$ & $\begin{array}{l}1833969,5 \\
1550543,5 \\
\end{array}$ & $\begin{array}{l}1938124,0 \\
1680536,1\end{array}$ \\
\hline $\begin{array}{l}\text { WYNIK BRUTTO NA SPRZEDAŻY } \\
\text { Koszty sprzedaży i promocji } \\
\text { Koszty ogólnego zarządu } \\
\text { Amortyzacja } \\
\text { Pozostałe przychody operacyjne } \\
\text { Pozostałe koszty operacyjne }\end{array}$ & $\begin{array}{r}193388,0 \\
39776,7 \\
56597,1 \\
18256,9 \\
19535,9 \\
3331,0\end{array}$ & $\begin{array}{r}283426,0 \\
34859,9 \\
48583,2 \\
24107,6 \\
24732,8 \\
11058,8\end{array}$ & $\begin{array}{r}257587,9 \\
62866,3 \\
111744,8 \\
30842,4 \\
31387,2 \\
21165,1\end{array}$ \\
\hline $\begin{array}{l}\text { WYNIK NA DZIALALNOŚCI OPERACYJNEJ } \\
\text { Odsetki uzyskane } \\
\text { Pozostałe przychody finansowe } \\
\text { Odsetki do zapłacenia } \\
\text { Pozostałe koszty finansowe } \\
\text { w tym niezrealizowane ujemne różnice kursowe }\end{array}$ & $\begin{array}{r}94962,2 \\
34990,5 \\
24039,0 \\
50797,9 \\
102307,5 \\
24722,7\end{array}$ & $\begin{array}{r}189549,3 \\
38941,5 \\
37785,5 \\
55361,8 \\
193360,0 \\
19339,5\end{array}$ & $\begin{array}{r}62356,5 \\
51256,5 \\
79879,1 \\
58926,1 \\
68650,8 \\
5078,5\end{array}$ \\
\hline $\begin{array}{l}\text { WYNIK NA DZIALALNOŚCI GOSPODARCZEJ } \\
\text { Zyski nadzwyczajne } \\
\text { Straty nadzwyczajne }\end{array}$ & $\begin{array}{r}886,3 \\
3210,5 \\
514,2\end{array}$ & $\begin{array}{r}\mathbf{5 5 4 , 5} \\
553,0 \\
828,0\end{array}$ & $\begin{array}{r}65915,2 \\
117,8 \\
145,2\end{array}$ \\
\hline WYNIK BRUTTO & 3582,6 & 17279,5 & 65887,8 \\
\hline $\begin{array}{l}\text { PODATEK DOCHODOWY I POZOSTALE } \\
\text { OBOWIAZZKOWE OBCIAZZZENIA }\end{array}$ & 3155,5 & 4872,8 & 19571,7 \\
\hline WYNIK FINANSOWY NETTO & 427,1 & 12406,7 & 46316,1 \\
\hline
\end{tabular}

Stocznia podpisała w tym roku 19 nowych kontraktów na: 6 chemikaliowców, 2 statki typu Ro-Pax, 7 kontenerowców z nowej serii B178 i 4 z już produkowanej serii B170.

Pod koniec 1999 roku portfel zamówień zawierał w sumie 31 jednostek o wartości łącznej 1,2 mld USD. Zabezpiecza to pracę firmy do końca 2001 roku i pozwala na sklasyfikowanie jej na 12 miejscu wśród największych stoczni świata ( wg. klasyfikacji Clarkson Research Studies).

Realizacja 7 kontenerowców dla Chile i Niemiec wymaga modernizacji pochylni Wulkan II tak, aby można było budować statki o szerokości około $38 \mathrm{~m}$ i długości do $300 \mathrm{~m}$. Wyłączenie jej z eksploatacji jest jedną z przyczyn planowego zmniejszenia ilości oddanych armatorom jednostek. Plan na 2000 rok zakładał utrzymanie mocy produkcyjnych ( $w$ tym także zatrudnienia) na poziomie gwarantującym realizację podjętych znacznie wyższych zobowiazzań na 2001 rok. $\mathrm{Z}$ tego m.in. powodu, Stocznia uruchomi dodatkowo produkcję pokryw lukowych i zaangażuje się w budowę suwnicy dla modernizowanej pochylni.

Od początku lat 90-tych Stocznia Szczecińska S.A. realizuje strategię mającą na celu utworzenie struktury gospodarczej zbliżonej do funkcjonujących na świecie, w których przemysł okrętowy odgrywa istotną rolę. Planowano utworzenie grupy kapitałowej o zdy- 
wersyfikowanym zakresie produkcji, z szansą na kontrolowanie około $60 \%$ kosztów materiałowych budowanych statków. W referendum przeprowadzonym wśród załogi uzyskano poparcie dla takiego rozwiązania. Założono również, że procedury zastosowane przy restrukturyzacji firmy będą odpowiadać światowym standardom.

W skład planowanej grupy przemysłowej miały wejśc m.in.: Stocznia Szczecińska, Stocznia Gdynia, Zakłady mechaniczne H.Cegielskiego w Poznaniu, Towimor w Toruniu, Huta Częstochowa, PŻM i inne. Pomysł upadł ostatecznie w 1994 roku.

Zdecydowano się wobec tego na budowę własnego holdingu. Jednym ze stosowanych sposobów było nabywanie kontrolnych pakietów w wybranych firmach kooperujących ze Stocznią. Wiele $\mathrm{z}$ nich było $\mathrm{w}$ tym momencie $\mathrm{w}$ trudnej sytuacji finansowej, kilka spółek przejęto również od banków w zamian za wierzytelności (tabl.3).

Na koniec 1999 roku holding liczył 21 spółek, których działalność skupia się wokół branż: stoczniowej, maszynowej, paliwowej, usługowo-hotelarskiej i logistycznej. Od maja 1999r. jej nazwa brzmi: „Stocznia Szczecińska Porta Holding S.A." i jest największym zespołem gospodarczym na Pomorzu Zachodnim. Utworzona grupa złożona ze spółek powiązanych kapitałowo $\mathrm{i}$ funkcjonalnie staje się powoli $\mathrm{w}$ regionie największym pracodawcą, zatrudniając łącznie ok.12 tys. osób (sama Stocznia - ponad 8200 osób - tabl.4).

Obecnie statki stanowią około $80 \%$ wartości sprzedaży grupy. Jednak przy nie dającej się precyzyjnie przewidzieć koniunkturze światowej, ryzykiem jest opieranie się tylko na jednym segmencie produkcji. Stąd główne zadania dotyczą restrukturyzacji finansowej i organizacyjnej spółek holdingu. Strukturę kapitału akcyjnego holdingu w latach 1997 i 1999 przedstawiono na ryc. 2.

Pierwszym i głównym filarem holdingu jest Stocznia Szczecińska S.A. Jeszcze do niedawna była w grupie „, spółką - matką”, od 12.X.1999r stała się „spółką - córką”. Rozpoczęła ona działalność z początkiem stycznia 2000 roku, przy znacznie obniżonych kosztach, co daje szanse skutecznego konkurowania z rywalami.

Stocznia Szczecińska S.A. posiada certyfikaty potwierdzające wdrożenie Zintegrowanych Systemów Zarządzania: jakością, śodowiskowy oraz bezpieczeństwa i higieny pracy, opracowanych według międzynarodowych standardów ISO9001, ISO140011, BS 8800 /OH 18001.

Tab. 3. Zaangażowanie w innych podmiotach gospodarczych (powyżej 20\%) - $\quad$ stan na dzień 30.06.1999r.

\begin{tabular}{|l|l|c|l|}
\hline Lp. & NAZWA SPÓŁKI & $\begin{array}{l}\text { UDZIAL W } \\
\text { KAPITALE }\end{array}$ & $\begin{array}{l}\text { RODZAJ PROWADZONEJ } \\
\text { DZIALALNOŚCI }\end{array}$ \\
\hline 1 & $\begin{array}{l}\text { Porta Eko Cynk } \\
\text { Sp. z o.o. }\end{array}$ & $100,00 \%$ & $\begin{array}{l}\text { Cynkowanie ogniowe konstrukcji stalowych, } \\
\text { Cynkowanie galwaniczne }\end{array}$ \\
\hline 2 & Erison Sp. z o.o. & $100,00 \%$ & $\begin{array}{l}\text { Szkolenia, doradztwo w zakresie systemów } \\
\text { jakości (ISO, TQM), restrukturyzacja, tłu- } \\
\text { maczenia }\end{array}$ \\
\hline 3 & Porta Service Sp. z o.o. & $100,00 \%$ & $\begin{array}{l}\text { Usługi gastronomiczne, } \\
\text { Handel detaliczny art. Spożywczymi }\end{array}$ \\
\hline
\end{tabular}




\begin{tabular}{|c|c|c|c|}
\hline 4 & Porta Mare Sp. z o.o. & $100,00 \%$ & Usługi turystyczne, wczasowe \\
\hline 5 & Porta Transport Sp. z o.o. & $100,00 \%$ & Usługi transportowe, remonty pojazdów \\
\hline 6 & Porta Relax Sp. z o.o. & $100,00 \%$ & $\begin{array}{l}\text { Ushugi turystyczne, } \\
\text { Działalnośc rekreacyjna, sportowa }\end{array}$ \\
\hline 7 & Porta Petrol S.A. & $99,97 \%$ & Handel hurtowy paliwami \\
\hline 8 & Porta Ruch S.A. & $98,00 \%$ & $\begin{array}{l}\text { Remonty i konserwacja maszyn, } \\
\text { Sieci energetycznych i łączności }\end{array}$ \\
\hline 9 & Porta-Agra Sp. z o.o. & $92,00 \%$ & Produkcja rolno - spożywcza \\
\hline 10 & $\begin{array}{l}\text { Rypińskie Zakłady Okrę- } \\
\text { towe Sp. z o.o. }\end{array}$ & $80,00 \%$ & $\begin{array}{l}\text { Produkcja kołnierzy stalowych i części } \\
\text { maszyn }\end{array}$ \\
\hline 11 & Porta Hotele Sp. z o.o. & $79,87 \%$ & $\begin{array}{l}\text { Prowadzenie hoteli, handel artykułami spo- } \\
\text { zywczymi i przemysłowymi }\end{array}$ \\
\hline 12 & Porta Odra Sp. z o.o. & $74,99 \%$ & $\begin{array}{l}\text { Budowa i remonty statków, produkcja kon- } \\
\text { strukcji stalowych }\end{array}$ \\
\hline 13 & $\begin{array}{l}\text { ZREMB-Gorzów Wlkp. } \\
\text { S.A. }\end{array}$ & $60,74 \%$ & $\begin{array}{l}\text { produkcja konstrukcji stalowych hal, mo- } \\
\text { stów i innych, produkcja suwnic, chwyta- } \\
\text { ków, zawiesi linowych }\end{array}$ \\
\hline 14 & PTH Paria Sp. z o.o. & $56,00 \%$ & Usługi turystyczne \\
\hline 15 & Towimor SA & $53,05 \%$ & $\begin{array}{l}\text { Projektowanie i produkcja żurawi okręto- } \\
\text { wych, wciągarek oraz konstrukcji stalowych }\end{array}$ \\
\hline 16 & $\begin{array}{l}\text { 3S - Projektowanie Kon- } \\
\text { strukcji } \\
\text { Okrętowych Sp. z o.o. }\end{array}$ & $51,04 \%$ & $\begin{array}{l}\text { Projektowanie konstrukcji okrętowych, } \\
\text { badania naukowe }\end{array}$ \\
\hline 17 & Nord Sp. z o.o. & $51,01 \%$ & $\begin{array}{l}\text { Produkcja urządzeń rozdzielczych, układów } \\
\text { sterowania i automatyki, pomiarowych } \\
\text { i kontrolnych }\end{array}$ \\
\hline 18 & $\begin{array}{l}\text { Allround Ship Service Sp. } \\
\text { z o.o. }\end{array}$ & $51,00 \%$ & $\begin{array}{l}\text { Zabezpieczenia antykorozyjne statkow, } \\
\text { usługi montażowo - spawalnicze dla prze- } \\
\text { mysłu stoczniowego }\end{array}$ \\
\hline 19 & Norstet Marine AS & $51,00 \%$ & Działalność akwizycyjna dla SS S.A. \\
\hline 20 & Stocznia Ustka SA & $50,09 \%$ & $\begin{array}{l}\text { Prod. Konstrukcji stalowych i aluminio- } \\
\text { wych, lodzi ratunkowych zrzutowych, jed- } \\
\text { nostek pływających z laminatu }\end{array}$ \\
\hline 21 & Centromor SA & $21,17 \%$ & Pośrednictwo handlowe \\
\hline
\end{tabular}




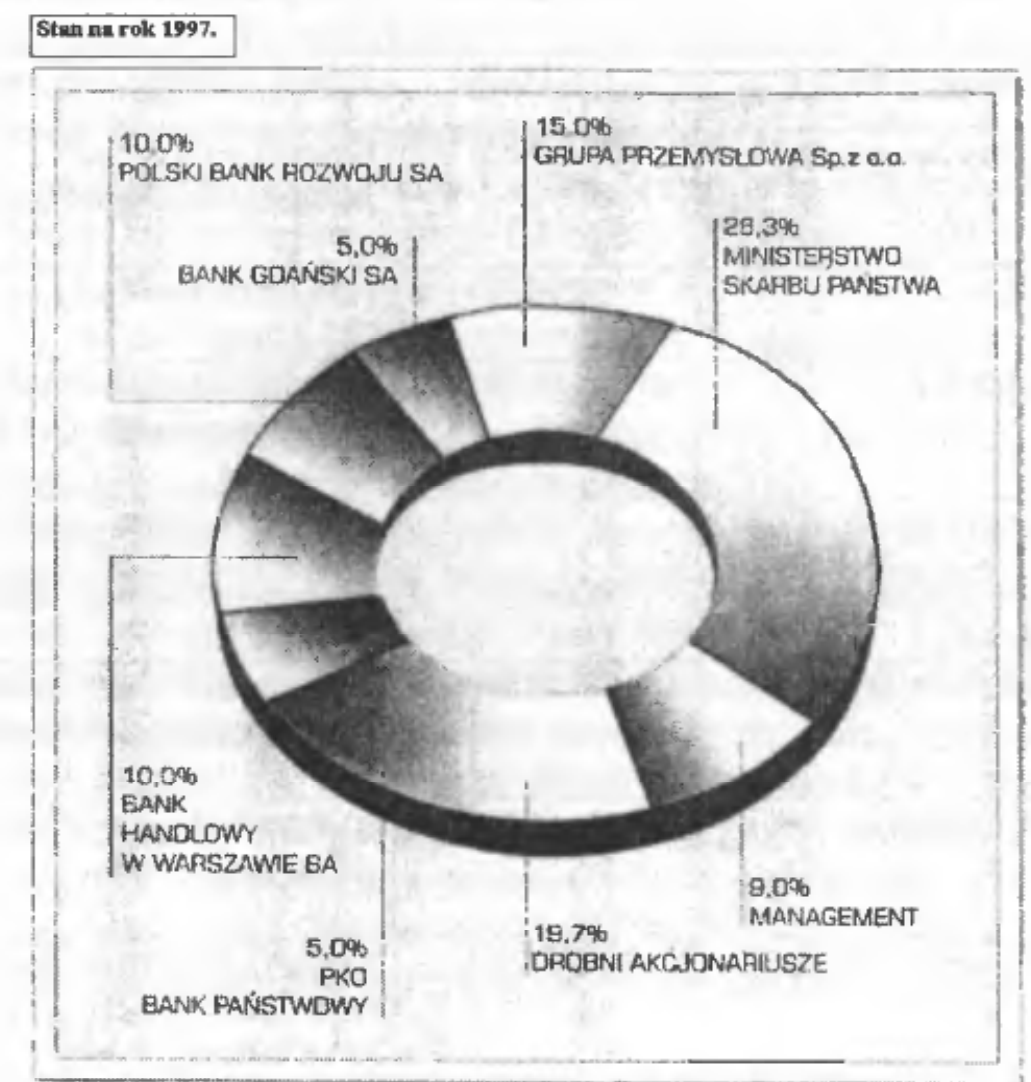

\begin{tabular}{|c|c|c|c|c|c|}
\hline \multicolumn{6}{|l|}{ STAM NA DZIEN $30.06 .1999 \mathrm{r}$} \\
\hline & thost & stauk- & & ILosc & \\
\hline WYSZCZEGOLLIENIE & Akert & TURA\% & 1 & Gtosobw & UDLIAL\% \\
\hline Grupa Przentystowa Sp. z 0.0. & 3000000 & $25,26 \%$ & 2 & 6000000 & 32,223 \\
\hline Porta Petroi S.A. & 2500000 & $21,05 \%$ & 1 & 2500000 & $13.43 \%$ \\
\hline Skab Pafistwa & 1182968 & $9.97 \%$ & 1 & 1182968 & $6,35 \%$ \\
\hline Bank Handlowy w Warsxtwie S.A. & 1000000 & $8,42 \%$ & 1 & 2000000 & $10.74 \%$ \\
\hline BrC Bank Cdasisse S. $\mathrm{A}$. & 500000 & $6,21 \%$ & 2 & 1000000 & $5,37 \%$ \\
\hline Oscby fizycane & 2793506 & $23,53 \%$ & 1 & 2793506 & $15,00 \%$ \\
\hline Osoby fizycze & 450000 & $3,79 \%$ & 3 & 2250000 & $12,06 \%$ \\
\hline Osoby fizycant & $\$ 47900$ & $3.77 \%$ & 2 & acs 800 & $4.81 \%$ \\
\hline SAZEM & 1874374 & $100 \%$ & & 18622274 & $100 \%$ \\
\hline
\end{tabular}

Rys. 2 Struktura kapitału akcyjnego "Stoczni Szczecińskiej Porta Holding S.A."

Czytelnicy Business Central Europe wybrali Stocznię Szczecińską najlepszą polską firmą1999 roku. Wspomniany magazyn naležy do grupy wydawnictw The Economist ukazujący się w kilkudziesięciu krajach. 
Tab. 4. Struktura zatrudnienia w Stoczni Szczecińskiej S.A. według grup i wykształcenia.

\begin{tabular}{|c|c|c|c|c|c|c|c|}
\hline Lp. & WYKSZTALCENIE & $\begin{array}{c}\text { PRAC. } \\
\text { FIZYCZNI }\end{array}$ & $\%$ & $\begin{array}{c}\text { PRAC. } \\
\text { UMYSLOWI }\end{array}$ & \% & RAZEM & $\%$ \\
\hline 1 & Brak wykszt. podstaw. & 9 & 0,1 & 1 & 0,05 & 10 & 0,1 \\
\hline 2 & Wykszt. podstawowe & 1196 & 19,0 & 53 & 2,7 & 1249 & 15,1 \\
\hline 3 & Wykszt. zasad. zawod. & 3873 & 61,5 & 128 & 6,6 & 4001 & 48,5 \\
\hline 4 & Wykszt. średnie-techn. & 1014 & 16,1 & 648 & 33,2 & 1662 & 20,1 \\
\hline 5 & Wykszt. średnie-ekon. & 21 & 0,3 & 124 & 6,4 & 145 & 1,8 \\
\hline 6 & Wykszt. średnie, ogólne & 174 & 2,8 & 171 & 8,8 & 345 & 4,2 \\
\hline 7 & Wykszt. wyższe-techn. & 8 & 0,12 & 593 & 30,4 & 601 & 7,3 \\
\hline 8 & Wykszt. wyższe-ekon. & 2 & 0,03 & 172 & $\mathbf{8 , 8}$ & $\mathbf{1 7 4}$ & 2,1 \\
\hline 9 & Wykszt. wyższe-inne & 1 & 0,01 & 61 & 3,1 & 62 & 0,8 \\
\hline 10 & Razem stan zatrudnienia & $\mathbf{6 2 9 8}$ & $\mathbf{1 0 0}$ & $\mathbf{1 9 5 1}$ & $\mathbf{1 0 0}$ & $\mathbf{8 2 4 9}$ & $\mathbf{1 0 0}$ \\
\hline
\end{tabular}

Drugim filarem jest Porta Petrol S.A. która dysponuje już uruchomionym na wiosnę b.r terminalem paliw w Świnoujściu. Przewiduje się, że spółka może docelowo osiągnąć poziom $70 \%$ sprzedaży stoczni, stanowiąc jednocześnie konkurencję dla innych dystrybutorów paliw na rynku polskim. Mając to na uwadze, umieszczono w planach na najbliższą przyszłość sukcesywną budowę tankowców rzecznych (tzw. bunkierek, o nośności ok.1,5 tys ton). Zyski będą zależeć od wielu czynników w tym także od zapotrzebowania rynku berlińskiego na paliwa.

Trzecim filarem może stać się Porta Eko Cynk S.A. Na bazie starej cynkowni stoczniowej zbudowano jeden z najnowocześniejszych w Europie zakładów. Spółka ma szansę w ciągu około 1,5 roku przejąć do $25 \%$ krajowego rynku usług. Oprócz zleceń ze stoczni, wykonywać będzie także usługi dla innych podmiotów gospodarczych m.in. na rynek budowy dróg i autostrad, dla energetyki i producentów konstrukcji stalowych.

Coraz lepiej radzą sobie także inne spółki, m.in. Porta Transport, która oprócz stoczniowych, wykonuje już około $25 \%$ zleceń pozyskanych poza grupa.

Najnowsza spółka holdingu to Porta Nova w Nowogardzie, która uruchomiła wytwórnię suszu ziemniaczanego. W latach 2000 i 2001 ma tu także powstać najnowocześniejsza w Polsce wytwórnia bioetanolu (m.in.do paliw). Aby zaspokoić potrzeby spółki nowogardzcy rolnicy powinny dostarczyć im zbiory żyta i ziemniaków z kilkunastu tys. ha. Może to znacznie poprawić sytuację rolników na tym terenie.

Zarząd holdingu zakłada, że w ciągu kilku lat grupa kapitałowa osiągnie obroty na poziomie 1 mld USD, przy 50\% udziale branży okrętowej. W 2001 roku przewiduje się, że holding będzie składał się już z 30 podmiotów gospodarczych.

Najważniejszym jest jednak fakt, że holding został już praktycznie sprywatyzowany a udziały Skarbu Państwa stanowią nieco poniżej 10\%. Zarząd holdingu planuje wprowadzenie w najbliższym czasie 2-5 spółek na Warszawską Giełdę Papierów Wartościowych. 


\section{Literatura}

Biuletyn Informacyjny Stocznia Szczecińska Porta Holding S.A., grudzień 1999r.

Klasa M., Do spótki spótka. 2000: najtrudniejszy rok Porty Holding., Kurier Szczeciński $\mathrm{z}$ dnia 21.I.2000r.

Od stoczni do holdingu (M.B.), Kurier Szczeciński z dnia 17.XI.2000r.

Piotrowski K., Formy organizacyjne polskiego przemystu okrętowego - grupa przemystowo-finansowa „Porta", [w]: IX Sejmik Morski - Przeksztatcenia wtasnościowe i strukturalne w gospodarce morskiej (Mielno-Koszalin,V.1993), Szczecin 1994.

Stocznia Szczecińska S.A. - raport roczny 1996.

Stocznia Szczecińska S.A. - raport roczny 1997.

50 lat Stoczni Szczecińskiej S.A.- raport roczny 1998. 